\title{
James MacGregor Burns, Williams College, the Jepson School, and the birth of leadership studies: an intellectual, and personal, remembrance
}

\author{
George R. Goethals \\ Professor, E. Claiborne Robins Distinguished Professorship in Leadership Studies, University of \\ Richmond, VA, USA
}

Scholars and thinkers have been pondering the mysteries of leadership for well over two millennia, perhaps even before Lao Tzu's aphorisms and Plato's concept of the Philosopher King (see Lipman-Blumen 2006). But Leadership Studies in modern academia owes its existence to James MacGregor Burns. As both a personal and professional force, Jim Burns pushed and prodded until leadership studies was created. I was fortunate enough to work with Burns for 35 years at Williams College, Jim's alma mater (Class of 1939) and academic home for most of his long and distinguished career. Then, after I left Williams for the Jepson School of Leadership Studies at the University of Richmond, which Jim helped shape in the early 1990s, I was able to stay in touch with him until near the very end. His loss leaves us without a warm, supportive personal friend and colleague, and a challenging conceptual mentor.

I first encountered the name James MacGregor Burns in December of 1960. I was in high school, waiting for a train in Boston's South Station shortly after John F. Kennedy had been elected President of the United States. At a newsstand, I picked up for 50 cents a copy of Burns' book John Kennedy: A Political Profile (1960). The back cover noted that Burns was a professor at Williams College. Nine years later I interviewed for a position in the Department of Psychology at Williams. The Department offered me an Assistant Professorship, but the war in Vietnam was raging and I was likely to be drafted. The Psychology chair mentioned that a colleague, Jim Burns, knew Massachusetts Senator Ted Kennedy, and that Burns could ask the Senator to speak to my draft board on Martha's Vineyard to arrange a deferment. This occurred about six months after Mary Jo Kopechne's tragic death in Kennedy's car on Chappaquiddick in July of 1969. The Senator was then on parole on Martha's Vineyard. I suggested that a Burns/Kennedy intervention there would likely backfire with local Selective Service officials.

In the end, I was able to take the Williams position, and my first sighting of Professor Burns also involved Ted Kennedy. Shortly after my arrival at Williams late in the summer of 1970, my wife and I and infant son went to hear Kennedy give a speech at Berkshire Community College, in Pittsfield, Massachusetts. Kennedy was running for re-election to the Senate, and it was unclear whether Chappaquiddick would end his political career. (Obviously, it did not.) When the floor was opened to discussion, a man who oddly seemed to be both warm personal friend and cool judgmental critic asked some sharp questions. The Senator parried gamely. I knew the man had to be Jim Burns. Burns had wondered aloud in his campaign biography of JFK whether that Kennedy stood for any great purpose. His relationship to 
the Kennedy family was complicated, and the complexity was clear that evening. The heart and head of James MacGregor Burns seemed to lean in opposite directions regarding the Kennedys.

Not long after, I called Jim, introduced myself, and asked whether he would be willing to meet with me and a group of students to discuss presidential leadership. In that initial encounter Burns introduced us to two lines of work on presidents by psychologically minded political scientists, James David Barber at Duke, and Fred Greenstein at Princeton. Among other things, this first meeting opened up for me an inspiring view of interdisciplinary thinking and research. Jim and I talked occasionally over the next year or two, until an afternoon I will always remember. Jim had walked across campus and, unannounced, knocked on my door, and asked if I had a few minutes to talk with him about leadership. Of course I did. He said he had been wrestling with the problem of understanding leadership for some time. He had written about leaders, such as Franklin Roosevelt in his Pulitzer Prize-winning book (Burns 1970), and on Kennedy, but he wanted to go beyond leaders, and to penetrate the fundamental dynamics of leadership itself. Influenced by Barber and Greenstein, among others, and his own thinking, he said, he had become convinced that in order to understand leadership, he needed to know more about human psychology, particularly the sources of motivation. We walked to the card catalog to see what motivation books were in the Psychology Library. As we talked about Abraham Maslow's motivational hierarchy, Jim seemed entranced. He immediately latched onto the idea that humans' motives can change, and that as lower motives are gratified, higher-level motives press for attention. In Maslow's formulation, for example, if the need for safety is gratified, people focus on the need for inclusion and belonging, and so forth, up to the motive of selfactualization, where people discover and strive to develop their full potentials, and define what is truly meaningful. In short, the implication was that motives can be satisfied and transformed. Jim then began pondering the idea that leaders can satisfy and thus transform the motives of followers. Some leaders, eventually called 'transactional leaders,' may only concern themselves with gratifying existing motives, but others would devote themselves to going beyond that and engaging followers' higher-level motives. Those leaders aspired to transform motives, and become 'transforming leaders.'

It may not have happened exactly that way, but my construction is that on a sunny, fall afternoon in 1971 or 1972, in the Bronfman Science Center's Psychology Library at Williams College, Jim Burns first generated the notion of 'transforming leadership.' In his 2003 book by the same title, Burns mentions that afternoon, in roughly the same way (Burns 2003, p. 9). Apparently, it was memorable for us both.

One recurring subject came up frequently as Jim and I talked during the 1970s: the Kennedys. Jim's conflicting attitudes and relationships with them were reflected in his 1976 book, Edward Kennedy and the Camelot Legacy, a book that is some ways harsher on its protagonist than Burns's earlier book on JFK, and in some ways more lauding. He wrote that Ted Kennedy was in some ways 'far better equipped' than John Kennedy had been 'to lead the nation.' At the time the book was published, the 44-year-old Ted Kennedy was still a plausible Democratic candidate for president. By then, Jim was fully occupied with the thinking and writing that culminated in the 1978 publication of Leadership, his first book on leadership itself rather than leaders (Burns 1978). He and I talked about leadership issues, and the Kennedys, both before and after that book was published. All of our conversations were helpful to me.

Early in the fall semester of 1983, I suggested to Jim that it might be worthwhile to have some kind of conference on the twentieth anniversary of President Kennedy's assassination. Typically, Jim agreed that it was a good idea, and, also typically, 
suggested that I should organize it. So I did. The result was an evening that showed the two delicately balanced but oppositional sides to Jim's approach to leaders, leadership, and John F. Kennedy. The event was an academically focused symposium. Jim was the anchorman. Before he spoke, I made remarks, as did a sociologist and an economist. It was a good, serious, interdisciplinary moment, the kind of thing that can happen when a small liberal arts college is functioning at its best. But by the time Jim finished, he had dramatically changed the intellectual and emotional tone of the evening. He had cautioned the three of us who preceded him to be tough-minded in our comments. We were, but in some ways, Jim was the most objective and analytical, and most critical of Kennedy among the four of us. But then he switched gears, and finished emotionally by reading a poignant Yeats poem that his pondering of JFK had called to mind. In watching and listening to Jim contemplating Kennedy, I think I learned more about the speaker than the subject of the evening. There were the two sides of Jim, the careful thinker and balanced critic, but also the emotional man who made clear his fascination with and attachment to specific leaders, especially this one, even though his overall project was to develop an intellectual study and analysis of leadership rather than leaders.

By this time Jim had turned 65 and was a 'professor emeritus' at Williams. He had begun to think about how a college might study leadership from a serious liberal arts, multidisciplinary perspective. And where better to undertake such an initiative than at his own alma mater, a top-notch undergraduate liberal arts school that pioneered outstanding interdepartmental, interdisciplinary programs in subjects such as Environmental Studies, American Civilization, and The History of Ideas? Those programs had begun under the active and innovative leadership of the President of Williams College from 1961 until 1973, Jim's 1939 classmate, John E. (Jack) Sawyer.

In what may have been a strategic mistake, Jim approached the project of instituting a Williams leadership studies program by first attempting to rally alumni support. His 50th college reunion in 1989 provided an opportunity. Jim organized a discussion among his classmates about a potential program and enlisted the support of none other than Jack Sawyer, who by that time had become legendary as a truly great leader in higher education - as the one who had transformed Williams from an all-male, fraternity-dominated party school in 1960 to an entirely non-Greek co-educational campus ten years later with a refreshed, forward-looking curriculum marked by creative academic and intellectual initiatives. Sometime after the reunion, Jim organized a group of alumni to meet at the Williams Club in New York to lobby again for leadership studies. Again, Jack Sawyer spoke on behalf of the project. One tangible result was a grant from the John M. Olin Foundation which supported Williams's first leadership course, taught in the Political Science Department during the spring of 1990 by Jim's colleague George Marcus.

Unfortunately, other than George Marcus's course, Jim's initial efforts to begin a leadership studies program at Williams did not flourish. As a retired faculty member, Jim simply did not have the institutional involvement and clout, despite his prominence among alumni, faculty who knew him, and the larger intellectual community. Jim did have conversations with Sawyer successors Francis Oakley and then Harry Payne about such a program, but at that point there needed to be more tedious, 'on the ground' pushing of faculty than Jim was in a positon then to mobilize. When Jim wrote about power, he focused on motivation and resource. He had the motivation, but he did not have the resources within the institution to achieve his goal. He was unable to engage in the gritty business of transactional leadership that was required to make Leadership Studies happen at Williams. Perhaps his fascination with transforming leadership 
rendered the mundane arts of transactional leadership less inviting. As he and I talked during those years, he made clear his disappointment, perhaps even bitterness, about the chilly reception that met his efforts toward leadership studies at Williams. I was preoccupied with administration as Provost at the time. Perhaps I could have and should have done more to help the cause. But, as often happens, the urgent was driving out the important, and in those years, leadership studies at Williams just never came to pass.

Partly as a result, I believe, of frustrations at Williams, Jim took an interest in leadership and leadership studies initiatives at other institutions. One of those institutions was the University of Richmond. At the same time that Jim was trying to get something going at Williams, the University of Richmond was well on its way to establishing what became the Jepson School of Leadership Studies. In the pivotal years of the late 1980s and early 1990s, Richard Morrill was President of the University of Richmond. He had met Jim Burns years earlier at Chatham College, where they had talked in depth about their mutual interests in values and leadership. As Richmond undertook a search for the Jepson School's first Dean, Morrill explored the possibility of engaging a Senior Fellow to help shape the school's curriculum and intellectual mission. In the Spring of 1990, with Howard Prince then in place as Dean, Morrill visited Williams College to explore with Jim the Senior Fellow position. I knew at the time that Jim was becoming involved with Richmond, but I was too busy with administration to pay much attention.

A few years later, Jim began a collaboration with Georgia Sorenson at the University of Maryland. Their joint efforts led first to the Center for Political Leadership \& Participation at Maryland, which later evolved into the James MacGregor Burns Academy of Leadership. All the while, when we could, Jim and I discussed these developments and his persisting vision of a leadership studies program at Williams. When my term as Provost came to an end in 1995, I took a sabbatical at the University of Massachusetts with the idea of returning to mainstream social psychology. As the year developed, I remember telling Jim that that re-entry seemed unsatisfying. He then must have sensed that this was the moment to draw a potential ally, long interested in leadership, into the struggle for a leadership studies program. He, and others, persuaded me to teach a course called Leadership in the Psychology Department. It was first offered in the spring of 1997. At Jim's urging I allowed a number of alumni to audit the course. I should not have been surprised when a gracious dinner they hosted turned out to have had an agenda. The alumni pressed me to press the Williams administration, now led by President Harry Payne, to support an interdepartmental Program in Leadership Studies, on the model of programs such as Environmental Studies or Biochemistry and Molecular Biology. While Jim merely offered words of encouragement from the sidelines, it was clear that he had choreographed some of these developments.

Getting the Program in Leadership Studies fully established at Williams took five years, and some doing. Some faculty wondered whether there really was anything to the subject of leadership while a smaller but more intense group worried that the study of leadership 'privileged' hierarchy, power, business, the military, and other, to them, bad things. In retrospect, my experience at Williams makes sense in terms of Richard Morrill's observation that the law and business faculties at Richmond 'got it' about leadership studies before the arts and sciences faculty. At Williams, there were no potential law and business allies. If it had not been for Jim's persistence I would have abandoned the effort. Finally, in 2003, the program was overwhelmingly approved by the faculty. Jim Burns was extremely gratified that Leadership Studies had become, after nearly 15 years of effort, a reality at his beloved college. Moreover, he was delighted to have a psychologist play a significant role in the new program, as 
his own interest in the psychological aspects of leadership were an important part of his early thinking about leadership.

Now, however, my collaboration with Jim on matters of leadership took place more often in Richmond than in Williamstown. Starting in 2001, Jim drew me into an effort centered at the Jepson School to develop a 'unified theory of leadership.' Along with the Jepson faculty, Jim, Georgia Sorenson and I worked from the fall of 2001 through 2004 on an endeavor we ended up calling 'The Quest for a General Theory of Leadership,' which eventually led to a 2006 book by that name co-edited by Sorenson and myself (Goethals and Sorenson 2006). During those same years, Georgia and I, with Jim as Senior Editor, developed the Encyclopedia of Leadership, published by Sage in 2004 (Goethals et al. 2004). This collaboration was greatly facilitated by the fact that I had a leave at Jepson in the spring of 2004, and Jim and Georgia and were also visiting faculty at Jepson during that semester.

The venue for my continued relationship with Jim decidedly became Richmond rather than Williamstown when I accepted an appointment as a professor in the Jepson School to start in the spring of 2006. We worked together in the fall of that year. Along with the late Mark Walker, I had planned the 'scholar' portion of the program of the International Leadership Association convention in Chicago, and urged Jim to join a symposium with Jepson faculty on 'The Quest.' At that same meeting Jim also led a discussion on a subject of enduring personal fascination, John F. Kennedy. The occasion was the publication of Jim's 2006 book, Running Alone: Presidential Leadership from JFK to Bush II - Why It Has Failed and How We Can Fix It. The book traces the way the imperial presidency grew out of Kennedy's strategy of depending more on his personal relationships and resources and less on the Democratic Party when he ran for president in 1960. Jim's presentation was personal and poignant. Though the book reflects James MacGregor Burns's head, Jim's presentation was from the heart. He recalled in some detail the mid-term election campaign of 1958, when both he and John Kennedy were on the ballot in Western Massachusetts, Jim as the Democratic candidate for the House of Representatives, in the heavily Republican First Congressional District, and Kennedy as candidate for re-election to the Senate. Jim recalled Kennedy coming by his house to pick him up for a joint appearance, and the Senator's cordiality and kindness. As was often the case, JFK was a man in a hurry, but he did take time to speak to Jim's children. Clearly, the moment entranced Jim, and he became quite emotional as he related it.

The penultimate time that Jim and I worked together was at the Jepson Prelude in the fall of 2009. Prelude is the moment when sophomores who have been admitted to Jepson are officially 'inducted' into the School. Rather than give a prepared speech, Jim asked that I interview him about his views on the central principles of leadership. Not surprisingly, the talk turned to Jim's earliest hero, Franklin D. Roosevelt, a paragon of transforming leadership. It seemed that the students did appreciate that they were hearing from the man who was so central in originating leadership studies, both in the academy internationally, and at Richmond locally.

The last time Jim and I had a chance to talk was in April of 2012. I had flown up to Williamstown and visited Jim at his home. He had broken a toe and strained his knee and was in no shape to leave the house. He was very aware of his upcoming 94th birthday. I was working on a book on presidential leadership and African Americans, and wanted to discuss Theodore Roosevelt with Jim. As always, Jim pressed me as to what I thought of TR in relation to race issues. I expressed my disappointments with the way this energetic, brilliant, and progressive leader dealt with black soldiers after the turmoil in Brownsville, Texas in 1906 and his support for 'lily 
white' Southern delegations to the Progressive Party convention in 1912. Jim heard me out, agreed that those were troublesome events, but encouraged me to think as thoroughly as I possibly could about Roosevelt, and then make clear my own position. It was vintage Jim Burns.

We never met again. But I know that I was very lucky to have first learned about Jim Burns's writing well over 50 years ago, and to have had his friendship, mentorship, and colleagueship for over 40 years. I still treasure my beat-up 50 cent paperback copy of John Kennedy: A Political Profile, and the author's inscription. All of us who knew James MacGregor Burns, Jim Burns, are better off for his life and work.

\section{REFERENCES}

Burns, James MacGregor (1960), John Kennedy: A Political Profile, New York: Harcourt. Burns, James MacGregor (1970), Roosevelt: Soldier of Freedom, New York: Harcourt, Brace, Jovanovich.

Burns, James MacGregor (1976), Edward Kennedy and the Camelot Legacy, New York: Norton. Burns, James MacGregor (1978), Leadership, New York: Harper \& Row.

Burns, James MacGregor (2003), Transforming Leadership, New York: Atlantic Monthly Press. Burns, James MacGregor (2006), Running Alone: Presidential Leadership from JFK to Bush IIWhy It Has Failed and How We Can Fix It, New York: Basic Books.

Goethals, George R. and Georgia L.J. Sorenson (eds) (2006), The Quest for a General Theory of Leadership, Cheltenham, UK and Northampton, MA: Edward Elgar.

Goethals, George R., Georgia J. Sorenson, and James MacGregor Burns (2004), Encyclopedia of Leadership, New York: Sage.

Lipman-Blumen, Jean (2006), The Essentials of Leadership, in G.R. Goethals, S.T. Allison, Roderick M. Kramer, and David M. Messick (eds), Conceptions of Leadership: Enduring Ideas and Emerging Insights, New York: Palgrave Macmillan. 